\title{
Extraction of Essential Oils from Lime (Citrus latifolia Tanaka) by Hydrodistillation and Supercritical Carbon Dioxide
}

\author{
Ana Cristina Atti-Santos ${ }^{1,2 *}$, Marcelo Rossato ${ }^{1,3}$, Luciana Atti Serafini ${ }^{1,2}$, Eduardo Cassel $^{4}$ \\ and Patrick Moyna ${ }^{5}$ \\ ${ }^{1}$ Instituto de Biotecnologia; ${ }^{2}$ Departamento de Física e Química; ${ }^{3}$ Departamento de Ciências Exatas e da Natureza; \\ Universidade de Caxias do Sul; Rua Francisco Getúlio Vargas 1130; 95.001-970; Caxias do Sul - RS - Brazil. ${ }^{4}$ \\ Pontifícia Universidade Católica do Rio Grande do Sul; Faculdade de Química; Av. Ipiranga 6681; 90.619-900; \\ Porto Alegre - RS - Brazil. ${ }^{5}$ Facultad de Quimica; Cátedra de Ciência y Tecnologia de Alimentos; UR, 11800; \\ Montevideo - Uruguay
}

\begin{abstract}
In this work lime essential oils were extracted by hydrodistillation and supercritical carbon dioxide. In the case of hydrodistillation, the parameters evaluated were extraction time and characteristics of the plant material. In supercritical extraction, the parameters evaluated were temperature, pressure, $\mathrm{CO}_{2}$ flow, extraction time and material characteristics. Considering citral content, the best results for hydrodistillation were obtained with a distillation time of 3 hours using whole peels. The best results for supercritical extraction were found using $60^{\circ} \mathrm{C}$, 90 bar, at a $\mathrm{CO}_{2}$ flow rate of $1 \mathrm{~mL} / \mathrm{min}$ for 30 minutes using milled peels. The best yields of lime oil were obtained by hydrodistillation $(5.45 \% \mathrm{w} / \mathrm{w})$ and supercritical extraction $(7.93 \% \mathrm{w} / \mathrm{w})$ for milled peels.
\end{abstract}

Key words: Citrus latifolia, lime, d-limonene, supercritical carbon dioxide, hydrodistillation

\section{INTRODUCTION}

Citrus oils are mixtures of very volatile components as terpenes and oxygenated compounds (Sato et al., 1996). Limonene, a monoterpene, is the major component of lime and other related citrus essential oils (Lanças and Cavicchioli, 1990). These oils are used in the pharmaceutical, perfumery and food industries (Huet, 1991), and the quality of the oils is related to the value of total aldehydes, basically citral content, which is between 4-5\% (Shaw, 1979).

The common commercial methods to produce the oils from citrus fruits and peels are machine coldpressing and distillation. However, the oils obtained by distillation deteriorate easily and develop off-flavors due to the instability of the terpene hydrocarbons present, particularly $d$ limonene (Yamauchi and Sato, 1990). Supercritical fluid extraction is an advantageous alternative process for refining citrus oils due to its low operating temperature and the absence of solvent residues (Iwai et al., 1994). Studies with mandarin oils have shown good yield results in comparison with other extraction processes (AttiSantos et al., 2000). In this work we report the influence of some extraction parameters on the composition of the lime oil obtained by hydrodistillation and supercritical carbon dioxide extraction.

*Author for correspondence 


\section{MATERIALS AND METHODS}

\section{Raw Material}

The unripe fruits were collected from the local market in São Sebastião do Caí. The peels were manually removed and dried at $36^{\circ} \mathrm{C}$ for 10 days. The material was stored in a room with controlled temperature $\left(25^{\circ} \mathrm{C}\right)$ and humidity $(60 \%)$. Experiments were performed with whole peels and peels milled with a cutting mill (TECNAL, type Willye TE650) to particles of $2.0 \mathrm{~mm}$.

\section{Hydrodistillation}

Samples of $60 \mathrm{~g}$ of lime peels were extracted by hydrodistillation using a modified Clevenger apparatus (Mechkovski and Akerele, 1992). The parameters evaluated to find the best conditions to obtain higher concentrations of oxygenated compounds were extraction time ( 1 to 8 hours) and type of material (whole and milled). The separated oils were dried over anhydrous sodium sulfate (Merck, Germany). Samples were stored in a refrigerator $\left(+6^{\circ} \mathrm{C}\right)$ until $\mathrm{GC}$ and $\mathrm{GC} / \mathrm{MS}$ analysis.

\section{Supercritical fluid extraction}

A Hewlett Packard 7680 extraction module was used to perform all the experiments. The material to be extracted was loaded into a thick-walled stainless steel thimble self-sealing extraction cell of $7.0 \mathrm{~mL}$ internal volume. Samples of $1.0 \mathrm{~g}$ of whole lime peels were extracted with supercritical carbon dioxide according to the procedure described and experiments to optimize the extraction conditions were carried out. The parameters evaluated were temperature and pressure $\left(40\right.$ to $60^{\circ} \mathrm{C}$ and 90 to 110 bar, respectively). All other variables were kept constant using milled material, with $2.0 \mathrm{~mL} / \mathrm{min}$ $\mathrm{CO}_{2}$ flow, 10 minutes equilibrium time, 30 minutes extraction time (Paroul et al., 2002). The best conditions established for temperature and pressure were used in the next series of experiments, changing the $\mathrm{CO}_{2}$ flow and the extraction time, defining the best conditions (based on a higher percentage of citral). The extracts were deposited in an internal trap and rinsed off into a vial with $1 \mathrm{~mL}$ of hexane and the oil yields were determined in each case.

\section{Analysis}

GC analyses were performed with a Hewlett Packard 6890 Series, equipped with a HP-
Chemstation data processor and fitted with a HPInnowax bonded phase capillary column $(30 \mathrm{~m} \mathrm{x}$ $320 \mu \mathrm{m}$ i.d., $0.50 \mu \mathrm{m}$ film thickness; Hewlett Packard, Palo Alto, USA). Column temperature, $40^{\circ} \mathrm{C}(8 \mathrm{~min})$ to $180^{\circ} \mathrm{C}$ at $3^{\circ} \mathrm{C} / \mathrm{min}, 180-230^{\circ} \mathrm{C}$ at $20^{\circ} \mathrm{C} / \mathrm{min}, 230^{\circ} \mathrm{C}(20 \mathrm{~min})$; injector temperature, $250^{\circ} \mathrm{C}$; detector temperature $250^{\circ} \mathrm{C}$; carrier gas $\mathrm{H}_{2}$ (34Kpa); split ratio 1:50, volume injected $1 \mu \mathrm{L}$ diluted in hexane (1:10) for hydrodistillation samples and $1 \mu \mathrm{L}$ neat for supercritical extraction samples.

The GC/MS analyses were performed in a 6890/MSD5973 Hewlett Packard gas chromatograph with a mass selective detector, equipped with HP Chemstation software and using Wiley 275 spectra data. A fused silica capilar column HP-Innowax $(30 \mathrm{~m}$ x $250 \mu \mathrm{m}, 0.25 \mu \mathrm{m}$ film thickness; Hewlett Packard, Palo Alto, USA) was used. The temperature program was the same used for GC analysis. Interface temperature $280^{\circ} \mathrm{C}$; split ratio 1:100; carrier gas $\mathrm{He}(56 \mathrm{KPa})$; flow rate: $1.0 \mathrm{~mL} / \mathrm{min}$.; ionization energy $70 \mathrm{eV}$; mass range 40-350; volume injected $0.5 \mu \mathrm{L}$; solvent cut $3.5 \mathrm{~min}$.

The identification of individual components was based on comparison of their GC retention indices (RI) on polar columns and comparison of their mass spectra by GC/MS to those described in the literature (Adams, 1995).

Quantification of Supercritical Extraction Samples Quantitative analyses of extracts were carried out by GC for both kinds of materials after establishing the optimal parameters. Quantification was achieved using suitable internal standards: 3octanol (97\% pure, Aldrich, USA) and hexadecane (98\% pure, Fluka, Switerzland). The solutions were prepared in n-hexane (Merck, Germany) at concentrations of $40.2 \mathrm{~g} / \mathrm{L}$ and $40.66 \mathrm{~g} / \mathrm{L}$ and added to the extracts. The analyses were completed by injections of the samples in the GC/FID. Extractions and injections were done in triplicate.

\section{RESULTS AND DISCUSSION}

In Fig. 1, the yields of lime essential oil obtained by hydrodistillation are shown. The yield increased up to five hours of distillation. 


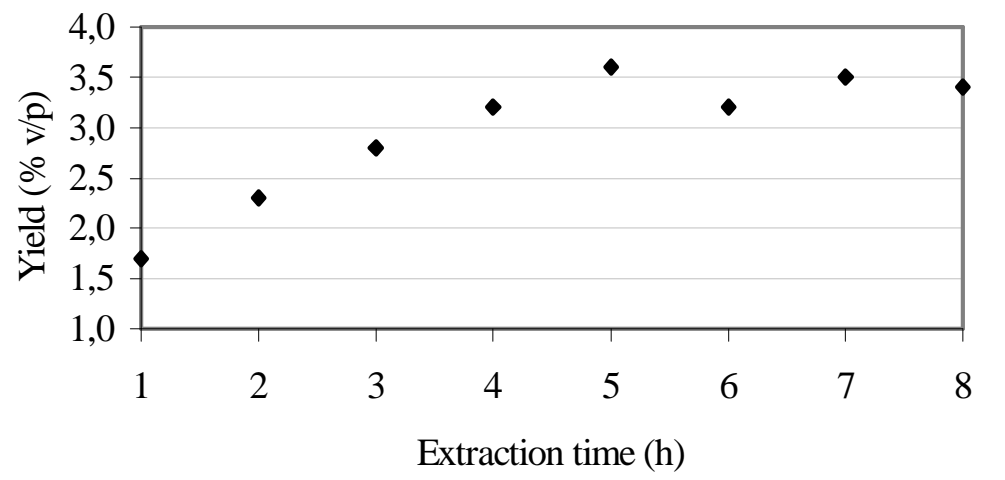

Figure 1 - Yield of the lime essential oil obtained by hydrodistillation

GC analysis of the lime oils obtained showed that the concentration of oxygenated compounds increased up to three hours of distillation. After this there was a gradual decrease in the concentration of these compounds. The apparent anomaly in the gradual decrease in oxygenated components with extended distillation times could be explained partially by the higher solubility of these components in the water phase, and partly due to the their progressive dilution in the distillate as the fraction of higher boiling hydrocarbon constituents gradually increased as the distillation went on (Table 1).
The results of the nine tests using supercritical extraction with variations of temperature $(40,50$ and $60^{\circ} \mathrm{C}$ ) and pressure (90, 100 and 110 bar), gave better results in terms of total nonoxygenated compounds at $60^{\circ} \mathrm{C} / 90$ bar (Table 2 ). The definition of the optimal operation conditions was based on the percentage of citral. With respect to this compound, higher yields observed with two different sets of conditions: $60^{\circ} \mathrm{C} / 90 \mathrm{bar}$ and $50^{\circ} \mathrm{C} / 100$ bar. At $50^{\circ} \mathrm{C} / 100$ bar, higher citral content was obtained, but the total compounds area was lower relative to the other set of conditions. Due to this, the selected conditions for further experiments were $60^{\circ} \mathrm{C}$ and 90 bar.

Table 1 - Lime oil percentage of the oxygenated and non oxygenated compounds extracted by hydrodistillation

\begin{tabular}{cccccccccccc}
\hline & $\mathbf{1 h}$ & $\mathbf{2 h}$ & $\mathbf{3 h}$ & $\mathbf{4 h}$ & $\mathbf{5 h}$ & $\mathbf{6 h}$ & $\mathbf{7 h}$ & $\mathbf{8 h}$ \\
\hline non-oxygenated & 83.7 & 81.5 & 81.2 & 85.0 & 82.6 & 85.4 & 84.8 & 86.1 \\
oxygenated & 14.9 & 17.0 & 17.0 & 13.1 & 15.3 & 13.5 & 12.1 & 11.7 \\
citral & 9.7 & 11.0 & 11.1 & 8.2 & 9.5 & 7.4 & 6.5 & 6.3 \\
total & 98.7 & 98.5 & 98.3 & 98.1 & 97.9 & 98.8 & 96.8 & 97.8 \\
\hline
\end{tabular}

Table 2 - Integration area of compounds of lime oils obtained by SFE in different operation conditions

\begin{tabular}{cc|c|c|c|c|c|c|c|c}
\hline & \multicolumn{10}{c}{ Temperature $\left({ }^{\circ} \mathbf{C}\right) /$ pressure (bar) } \\
\hline & $\mathbf{4 0 / 9 0}$ & $\mathbf{5 0 / 9 0}$ & $\mathbf{6 0 / 9 0}$ & $\mathbf{4 0 / 1 0 0}$ & $\mathbf{5 0 / 1 0 0}$ & $\mathbf{6 0 / 1 0 0}$ & $\mathbf{4 0 / 1 1 0}$ & $\mathbf{5 0 / 1 1 0}$ & $\mathbf{6 0 / 1 1 0}$ \\
\hline non-oxygenated & 8,401 & 6,801 & 8,903 & 7,212 & 8,399 & 8,676 & 7,025 & 5,622 & 6,204 \\
oxygenated & 436 & 370 & 474 & 381 & 485 & 454 & 384 & 312 & 319 \\
citral & 202 & 164 & 207 & 172 & 219 & 204 & 173 & 136 & 139 \\
total & 8,837 & 7,172 & 9,377 & 7,594 & 8,885 & 9,131 & 7,410 & 5,935 & 6,524 \\
\hline
\end{tabular}




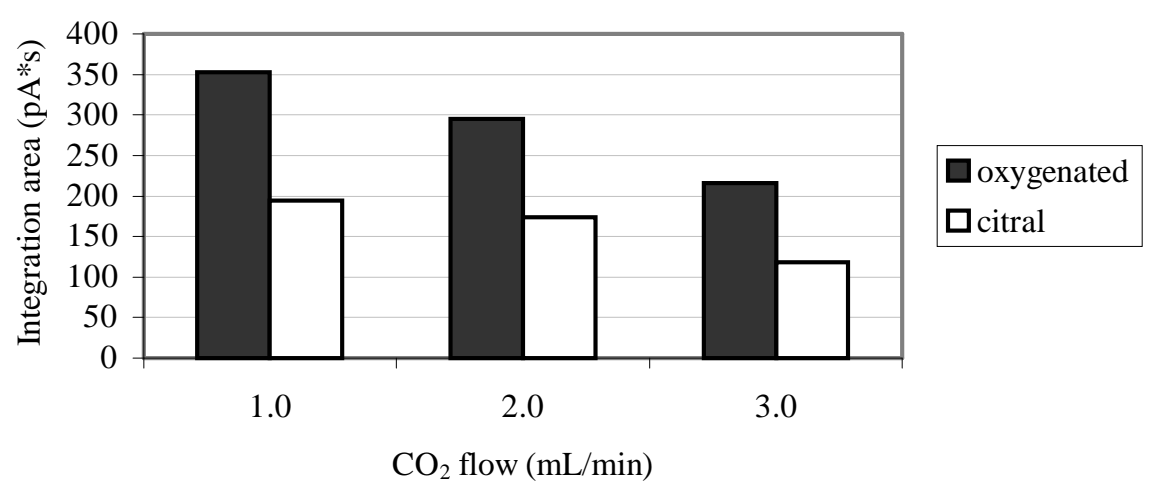

Figure 2 - Integration area of oxygenated compounds and citral of lime oils obtained by SFE in different conditions of $\mathrm{CO}_{2}$ flow

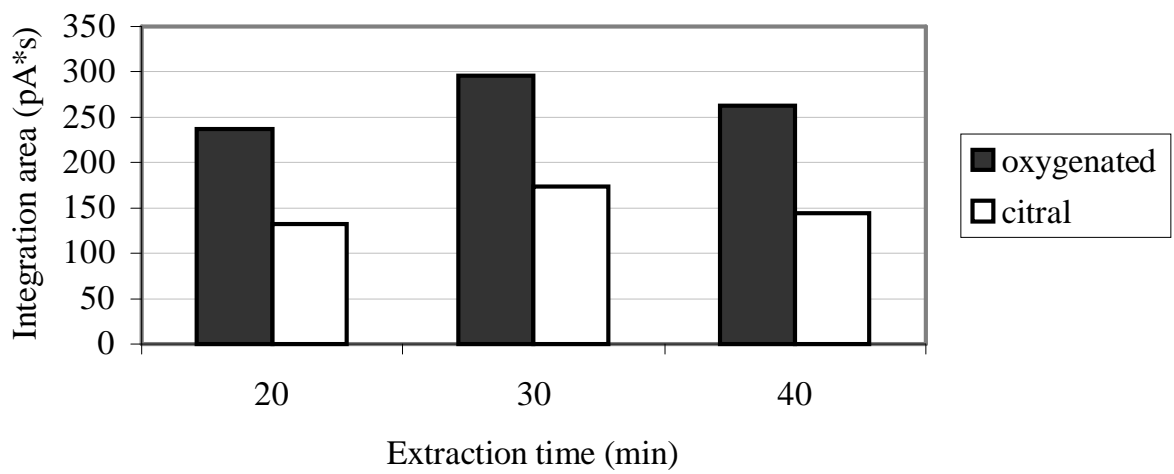

Figure 3 - Integration area of oxygenated compounds and citral of lime oils obtained by SFE in different extraction times

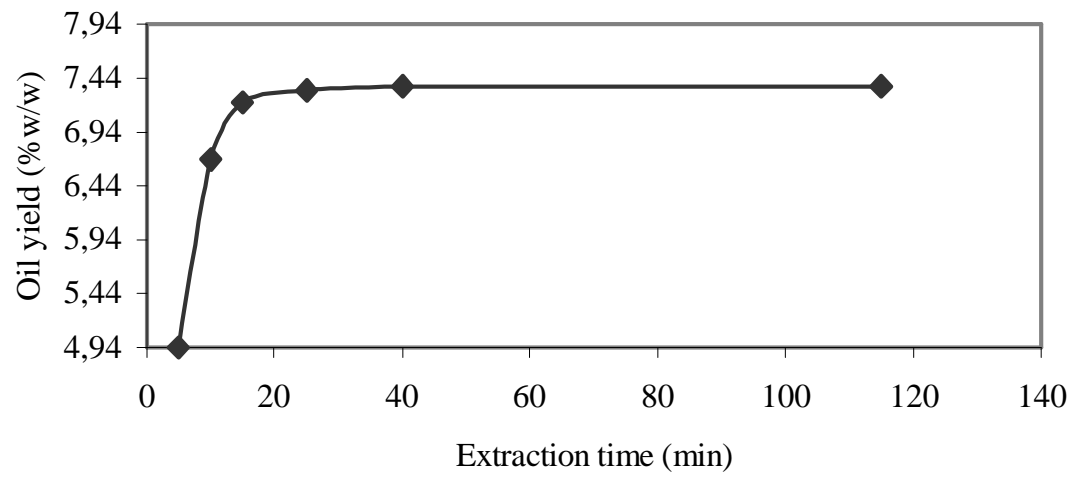

Figure 4 - Essential oil yield of lime milled peels obtained by SFE in different extraction lime 
In these pressure and temperature conditions, the influence of $\mathrm{CO}_{2}$ flow rate on the essential oil composition was evaluated using flow of 1.0, 2.0 and $3.0 \mathrm{~mL} / \mathrm{min}$ (Fig. 2). As observed, an increased in the $\mathrm{CO}_{2}$ flow rate increases the extraction of non-oxygenated compounds from the essential oil, while a lower $\mathrm{CO}_{2}$ flow rate led to higher contents of citral. Hence, a flow of 1.0 $\mathrm{mL} / \mathrm{min}$ was selected.

With respect to process time, the best results were obtained at 30 minutes (Fig. 3). The reduction observed at 40 minutes could be justified by entrapment of light compounds by $\mathrm{CO}_{2}$.
Fig. 4 showed that all the essential oil was extracted at 30 minutes. Quantitative results showed the superiority of milled material $(7.93 \%$ w/w for $\mathrm{CO}_{2}$ extraction and $5.45 \%$ w/w for hydrodistillation) than the whole material $(1.98 \%$ w/w for $\mathrm{CO}_{2}$ extraction and $0.97 \%$ w/w for hydrodistillation).

Among the two tested methods, the supercritical extraction presented the lower process time. The most important result was in terms of chemical composition of essential oil, which presented similar amount of components comparing to a commercial sample cited by Koketsu et al (1983).

Table 3 - Percentage of the volatile components of lime oils obtained by different extraction process (hydrodistillation: $3 \mathrm{~h}$; supercritical extraction: $60^{\circ} \mathrm{C}, 90 \mathrm{bar}, 1 \mathrm{~mL} / \mathrm{min} \mathrm{CO}_{2}, 30$ minutes)

\begin{tabular}{lc|c|c|c}
\hline Compound & Hydrodistillation & $\begin{array}{c}\text { Supercritical } \\
\text { extraction }\end{array}$ & $\begin{array}{c}\text { Commercial sample } \\
\text { (Koketsu et al., 1983) }\end{array}$ & $\begin{array}{c}\text { Retention } \\
\text { index }\end{array}$ \\
\hline$\alpha$-pinene & 1.9 & 2.7 & $4.31-5.03$ & 1025 \\
$\alpha$-thujene & 0.5 & 0.8 & - & 1021 \\
$\beta$-pinene & 12.4 & 14.5 & $14.58-16.04$ & 1100 \\
sabinene & 1.6 & 2.2 & $0.91-1.40$ & 1118 \\
myrcene & 1.2 & 1.4 & $0.89-1.76$ & 1171 \\
$\alpha$-terpinene & 0.3 & 0.4 & $0.02-0.14$ & 1182 \\
d-limonene & 47.5 & 48.9 & $51.47-59.65$ & 1205 \\
$\gamma$-terpinene & 12.3 & 17.0 & $1.30-8.46$ & 1254 \\
para-cimene & 1.0 & - & $1.20-1.43$ & 1279 \\
$\alpha$-terpinolene & 0.6 & 0.7 & 0.33 & 1291 \\
linalool & 1.3 & 0.2 & $0.11-0.24$ & 1559 \\
cis- $\alpha$-bergamotene & 0.3 & 1.2 & $1.03-1.34$ & 1594 \\
terpinene-4-ol & 1.2 & 0.5 & $0.07-0.17$ & 1614 \\
neral & 4.7 & 0.7 & $0.48-1.17$ & 1694 \\
$\alpha$-terpineol & 2.2 & 0.4 & $0.16-0.35$ & 1708 \\
$\beta$-bisabolene & 1.8 & 3.3 & $0.24-0.53$ & 1739 \\
geranial & 6.4 & 1.1 & $2.23-3.93$ & 1746 \\
geranil acetate & 0.3 & 0.4 & $0.07-0.27$ & 1778 \\
nerol & 0.7 & - & 0.02 & 1811 \\
geraniol & 0.3 & - & $0.02-0.05$ & 1858 \\
non-oxygenated & 81.2 & 93.3 & & \\
oxygenated & 17.0 & 3.3 & & \\
citral & 11.1 & 1.8 & & \\
total & 98.3 & 96.6 & & \\
\hline
\end{tabular}

\section{ACKNOWLEDGEMENTS}

Research supported by Universidade de Caxias do Sul, Pontifícia Universidade Católica do Rio Grande do Sul and Secretaria de Estado da Ciência e Tecnologia - RS.

\section{RESUMO}

Neste trabalho o óleo essencial de lima ácida foi extraído por hidrodestilação e $\mathrm{CO}_{2}$ supercrítico. No caso da hidrodestilação, os parâmetros avaliados foram o tempo de processo e características do material vegetal. Em extração supercrítica, os parâmetros avaliados foram temperatura, pressão e fluxo do $\mathrm{CO}_{2}$, tempo de 
processo e características do material. Considerando o conteúdo de citral, os melhores resultados para hidrodestilação foram obtidos em um tempo de processo de 3 horas utilizando-se cascas inteiras. Os melhores resultados para extração supercrítica foram obtidos a $60^{\circ} \mathrm{C}, 90$ bar, a um fluxo de $\mathrm{CO}_{2}$ de $1 \mathrm{~mL} / \mathrm{min}$ para 30 minutos de processo utilizando-se cascas moídas. Os melhores resultados em termos de rendimento de óleo essencial foram obtidos por hidrodestilação $(5,45 \% \mathrm{p} / \mathrm{p})$ e extração supercrítica $(7,93 \% \mathrm{p} / \mathrm{p})$, para cascas moídas.

\section{REFERENCES}

Adams, R. P. (1995), Identification of essential oils components by gas chromatography/mas spectroscopy. Allured Publ. Corp., Carol Stream, IL.

Atti-Santos, A. C.; Cassel, E. and Atti-Serafini, L. (2000), Supercritical carbon dioxide extraction of essential oils from mandarin (Citrus deliciosa Tenore) from South Brazil. Perfumer and Flavorist, 25, 26-36.

Huet, R. (1991), Les huiles essentielles d'agrumes. Fruits, 46, 501-513.

Iwai, Y.; Hosotani, N.; Morotomi, T.; Koga, Y. and Arai, Y. (1994), High-pressure vapor-liquid equilibria for carbon dioxide + linalool. Journal of Chemical and Engineering Data, 39, 900-920.

Koketsu, M.; Magalhães, M. T.; Wilberg, V. C. and Donalisio, M. G. R. (1983), Óleos essenciais de frutos cítricos cultivados no Brasil. Rio de Janeiro.

Lanças, F. M. and Cavicchioli, M. (1990), Analysis of the essential oils of Brazilian citrus fruits by capillary gas chromatography. Journal of High Resolution Chromatography, 13, 207-209.

Mechkovski, A. and Akerele, C. O. (1992), Quality control methods for medicinal plant materials, WHO/PHARM/92.559. World Health Organization, Switzerland.
Paroul, N.; Rota, L. D.; Frizzo, C. D.; Santos, A. C. A.; Moyna, P. and Serafini, L. A. (2002), Chemical composition of angelica root oils obtained by hydrodistillation and supercritical $\mathrm{CO}_{2}$ extraction. Journal of Essential Oils Research, 14, 282-285.

Sato, M.; Goto, M. and Hirose, T. (1996), Supercritical fluid extraction on semibatch mode for the removal of terpenes in citrus oils. Ind. Eng. Chem. Res., 35, 1906-1911.

Shaw, P. E. (1979), Review of quantitative analysis of citrus essential oils. Journal of Agricultural Food Chem., 27, 246-257.

Yamauchi, Y. and Sato, M. (1990), Fractionation of lemon-peel oil by semi-preparative supercritical fluid chromatography. Journal of Chromatography, 550, 237-246.

Received: August 25, 2003 ; Revised: March 03, 2004; Accepted: July 02, 2004. 